\title{
Effectivity of Health Education with Telenursing on the Self-care Ability of Coronary Artery Disease Patients: A Systematic Review
}

\author{
Vanny Leutualy $^{1 *} \mathbb{D}$, Yanny Trisyani $^{2}$ iD, Nurlaeci Nurlaeci ${ }^{3}$ \\ ${ }^{1}$ Department of Emergency and Critical Care Nursing, Faculty of Health, Universitas Kristen Indonesia Maluku, Nusaniwe, \\ Indonesia; ${ }^{2}$ Department of Emergency and Critical Care Nursing, Faculty of Nursing, Universitas Padjadjaran, Bandung, \\ Indonesia; ${ }^{3}$ Departement of Cardiac Care Unit, Hasan Sadikin General Hospital, Bandung, Indonesia
}

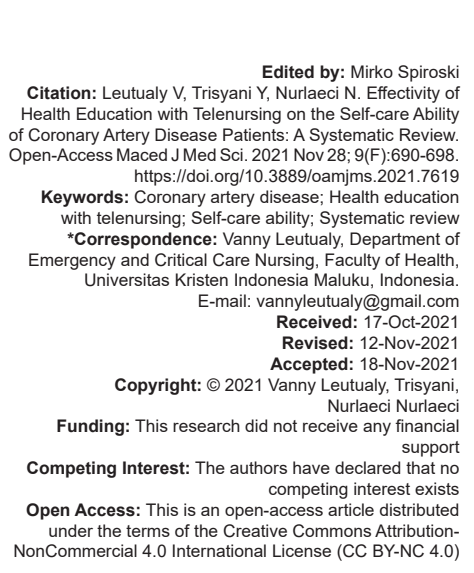

\section{Introduction}

Cardiovascular disease is the leading cause of death and disability globally [1]. More people die from cardiovascular disease every year than from other conditions [2]. The World Health Organization reports that more than 17.9 million people died in 2017 due to cardiovascular disease, representing $31 \%$ of deaths globally, and 17 million deaths occurred before 70 years of age. The highest case of cardiovascular disease is coronary artery disease (CAD) [3]. In Indonesia, the prevalence of CAD increased $1.5 \%$ or $15 / 1000$ in 2018 [4], while in West Java in 2014, the incidence of CAD was 514,597, the highest in Indonesia [5].

Atherosclerotic plaque rupture causes CAD to occur suddenly and is fatal before medical treatment can be given [6]. The dynamic nature of the CAD process results in a variety of clinical presentations, including; compression of the mid sternal or substernal, chest pain such as; cramps and burning, chest pain that can spread to the neck, jaw, shoulders, back to one or both arms, shortness of breath, or chest feels heavy, symptoms can include indigestion or belch with or without epigastric pain, nausea or vomiting, and diaphoresis [7], [8]. A typical condition of chronic artery disease is a chronic progressive, which causes patients to have a high risk of recurrence, recurrent hospitalization, and death [9].

The incidence of rehospitalization 30 days after hospitalization in CAD patients was $20 \%$ [10]. It is caused because many patients, even though they have been treated and received therapy, still do not adhere to the treatment plan and have habits that can cause recurrence [11]. So that patients after CAD attacks should receive secondary preventive interventions [10]. Some of the things mentioned above suggest that CAD involves various processes and is related to treatment and changes in the patient's life behavior that can be done through secondary preventive interventions so as not to cause fatal events.

Secondary prevention can be done as an effort to deal with CAD. The clinical benefit of secondary prevention on the prevention of relapse is more effective for CAD patients with a success rate of more 
than $75 \%$ [12]. One of the secondary prevention efforts that can be done is the management of risk factors and lifestyle modification, such as reducing the risk of atherosclerosis and adopting behavior [12], [13].

Efforts to control and modify risk factors can be made by providing health counseling and education about lifestyle changes [14].

Providing specific education about CAD to patients can affect the patient's self-care ability and can directly reduce the recurrence of $C A D$ and improve the patient's quality of life [15]

Technological developments in the modern era can be used to facilitate nurses in providing education for patients to improve the self-care abilities of CAD patients. Telenursing is a powerful health promotion method and knowledge to enhance patient cognitive skills, increasing patient self-care abilities [16].

Several studies have shown the effectiveness of telenursing in various countries [17], [18], [19], [20], [21].

This systematic review aimed to determine the effectiveness of health education interventions with telenursing on the self-care of CAD patients based on the implementation media. The literature clearly shows that health education by telenursing is an appropriate intervention for CAD patients to develop a healthy lifestyle in the process of healing and restoring their physical condition after being hospitalized in a hospital. Telenursing health education interventions are recommended for nurses to use in clinical areas to control and educate patients on an ongoing basis. The findings of this systematic review will inform nurses about the effectiveness of health education interventions by telenursing on the self-care abilities of CAD patients.

\section{Methods}

The design of this study was a systematic review and conducted based on items found in CINAHL EBSCO, PubMed, ScienceDirect, and Google Scholar from 2008 to 2019.

\section{Article search}

Reviewers minimize the potential for publication bias by conducting a systematic search by browsing electronic databases, including; ScienceDirect, PubMed, and CINAHL EBSCO, between 2008 and 2019. The combination of keywords uses English, namely, "Telenursing" OR "Text Messaging" OR "Phone calls" OR "m-health" OR "Teleconferences" OR "Telemonitoring" AND
"Self-Care" OR "Self-care monitoring" OR "Self-care Maintenance" OR "Self-Care Management" AND "CAD" OR "Coronary Heart Disease" AND "Randomized Controlled Trial" OR "Experimental Study" OR "QuasiExperiment" NOT "Literature review" NOT "Review literature" NOT "Overview" NOT "Systematic Review" NOT "Meta-analysis."

\section{Article selection}

The selection of articles in the systematic review refers to the Preferred Reporting Items for Systematic Reviews and Meta-Analyzes (PRISMA) flowchart.

Reviewers independently select articles from each selected database and then further determine which studies are worth assessing. Reviewers sort duplicated articles through titles found in the database. After that, due diligence is conducted on the full-text article by the criteria of inclusion and exclusion. Eligible research articles are included in articles that are then assessed and synthesized. Research articles that meet inclusion criteria are entry at bibliographic software (Mendeley).

The eligibility criteria used in a systematic review using the PICOS framework are as follows;

Population; Studies that focus on problems involving chronic and acute coronary artery disease patients, who have undergone hospitalization, aged $\geq 18$ years, can read and write with proper cognitive function, have a stable physical condition, patients and families have and can operate personal cell phones and able to manage the applications used to communicate.

Intervention; Telenursing health education interventions include; text messages, phone calls, $\mathrm{m}$-health, teleconferences, telemonitoring.

Comparison; Outcomes; Self-care abilities include; self-care maintenance, self-care monitoring, self-care

Study Design; RCT and quasi-experiment

Publication years; 2008-2019

Language; English and Indonesian

\section{Extraction data}

Extraction data included researcher citation, country, year of publication, intervention and control groups, sample and population, mean age (SD), outcome measure, time of measurement, and intervention effects.

\section{Quality appraisal}

The methodological quality of eligible studies was assessed independently by reviewers using the 
Joanna Briggs Institute (JBI) 2020 critical assessment checklist for randomized controlled studies and quasi-experiments. The JBI critical appraisal tools checklist for the randomized controlled trial was given a minimum score of $10(75 \%)$ of the total score of 13. Meanwhile, articles with a quasi-experimental study used the JBI critical appraisal tools checklist for a randomized controlled trial and were given a minimum score of $6(75 \%)$ of the total score of 9 . Each assessment will be read and corrected by the supervisor.

\section{Synthesis data}

Synthesis of data in a systematic review using a narrative summary (narrative synthesis).

\section{Results}

\section{Study selection results}

The study selection process in a systematic review uses the PRISMA flowchart. The study identification process on four databases; PubMed, CINAHL EBSCO, ScienceDirect, and Google Scholar, which use keywords; reviewers get 304 articles that match these keywords. The search results that had been obtained were then checked for duplications and found 108 of the same articles and issued so that 196 articles were left. Then, the reviewers conducted a screening based on the title adjusted to the systematic review topic, and as many as, 123 items were excluded, leaving 73 articles.

Furthermore, the articles were selected based on the availability of full text and the eligibility criteria. Seven relevant articles were obtained and used as the material in a systematic review. Seven articles that meet the inclusion criteria are divided into; six articles are RCT studies and one is a quasi-experimental study. All included studies are Level II in evidence-based practice [22]. Study selection in a systematic review is shown in Figure 1.

\section{Study quality and risk of bias}

The quality of the study of each article that was the source of a systematic review referred to the quality analysis of the JBI critical appraisal tools; articles with the type of RCT study were then subjected to critical assessment using the $\mathrm{JBI}$ critical appraisal tools checklist for randomized controlled trial independently by reviewers given a minimum score of 10 (75\%) of the total score 13 (Table 1). Meanwhile, articles with quasi-experimental studies or other clinical trials use

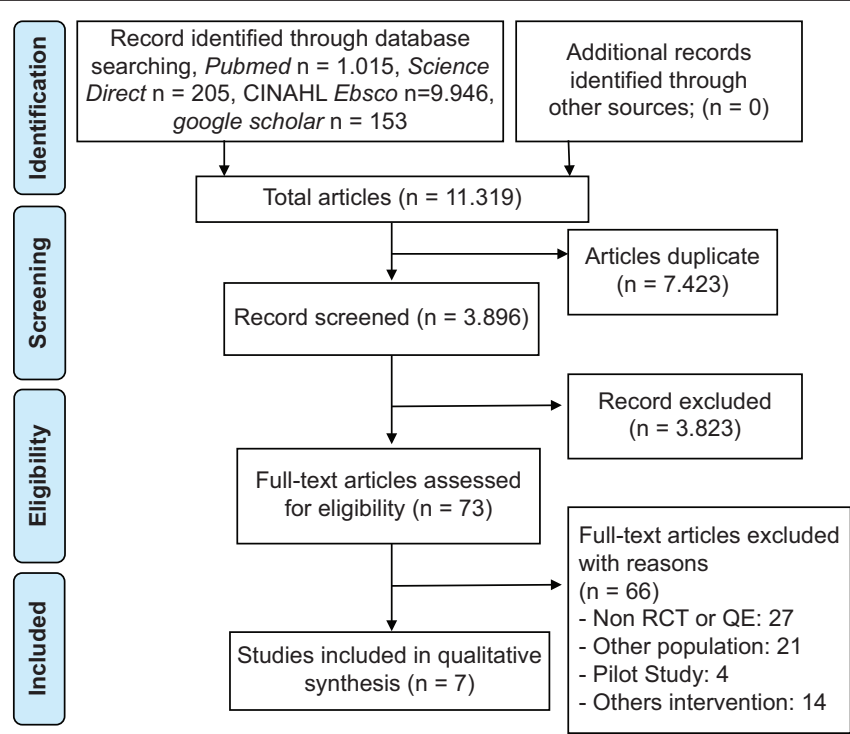

Figure 1: Selection flowchart

Table 1: Assessment results of a systematic review study using the JBI critical appraisal tools checklist for a randomized controlled trial

\begin{tabular}{|c|c|c|c|c|c|c|c|c|c|c|c|c|c|c|}
\hline \multirow[t]{2}{*}{ Author and year } & \multicolumn{13}{|c|}{ Criteria } & \multirow[t]{2}{*}{ SUM } \\
\hline & 1 & 2 & 3 & 4 & 5 & 6 & 7 & 8 & 9 & 10 & 11 & 12 & 13 & \\
\hline Holmes-Rovner et al. [20], 2019 & $\mathrm{Y}$ & $\mathrm{Y}$ & $\mathrm{Y}$ & $\mathrm{T}$ & $\mathrm{Y}$ & $\mathrm{Y}$ & $\mathrm{N}$ & $\bar{Y}$ & $\bar{Y}$ & $\mathrm{Y}$ & $\mathrm{Y}$ & $\mathrm{Y}$ & $\mathrm{Y}$ & $12 / 13$ \\
\hline Haider et al. [23], 2019 & Y & Y & Y & $\mathrm{T}$ & Y & $\mathrm{u}$ & $\mathrm{N}$ & Y & Y & Y & Y & Y & Y & 10/13 \\
\hline Santo et al. [24], 2018 & Y & Y & Y & $\mathrm{T}$ & Y & $\mathrm{U}$ & $\mathrm{N}$ & Y & Y & Y & Y & Y & Y & 10/13 \\
\hline Hawkes et al. [25], 2013 & $\mathrm{Y}$ & $\mathrm{Y}$ & $\mathrm{Y}$ & Y & Y & $\mathrm{Y}$ & $\mathrm{U}$ & $\mathrm{Y}$ & $\mathrm{Y}$ & Y & $\mathrm{Y}$ & $\mathrm{Y}$ & Y & $12 / 13$ \\
\hline Zheng et al. [26], 2019 & $\mathrm{Y}$ & $\mathrm{Y}$ & $\mathrm{Y}$ & $\mathrm{U}$ & Y & $\mathrm{Y}$ & Y & $\mathrm{Y}$ & Y & Y & $\mathrm{Y}$ & $\mathrm{Y}$ & Y & $12 / 13$ \\
\hline Holmes-Rovner et al. [20], 2008 & Y & $Y$ & $Y$ & U & U & U & $Y$ & Y & $Y$ & Y & Y & $Y$ & Y & 10/13 \\
\hline
\end{tabular}

the JBI critical appraisal tools checklist. They are given a minimum score of $6(75 \%)$ out of the total score of 9 (Table 2).

Table 2: Results of systematic review studies using the JBI critical appraisal tools checklist for quasi-experimental studies

\begin{tabular}{lllllllllll}
\hline Author & \multicolumn{2}{c}{ Criteria } & & & & & & SUM \\
\cline { 2 - 11 } & 1 & 2 & 3 & 4 & 5 & 6 & 7 & 8 & 9 & \\
\hline Tang et al. [18], 2018 & $\mathrm{Y}$ & $\mathrm{Y}$ & $\mathrm{Y}$ & $\mathrm{Y}$ & $\mathrm{Y}$ & $\mathrm{Y}$ & $\mathrm{Y}$ & $\mathrm{Y}$ & $\mathrm{Y}$ & $9 / 9$ \\
\hline Y: Yes. & & & & & & & & & &
\end{tabular}

1. Was true randomization used for assignment of participants to treatment groups?

2. Was allocation to treatment groups concealed?

3. Were treatment groups similar at the baseline?

4. Were participants blind to treatment assignment?

5. Were those delivering treatment blind to treatment assignment?

6. Were outcomes assessors blind to treatment assignment?

7. Were treatment groups treated identically other than the intervention of interest?

8. Was follow-up complete and if not, were differences between groups in terms of their follow up adequately described and analyzed?

9. Were participants analyzed in the groups to which they were randomized?

10. Were outcomes measured in the same way for treatment groups? 
11. Were outcomes measured in a reliable way?

12. Was appropriate statistical analysis used?

13. Was the trial design appropriate, and any deviations from the standard RCT design (individual randomization, parallel groups) accounted for in the conduct and analysis of the trial?

Based on Table 1, it can be seen that the average score of the total articles included is 11. These six articles show a low risk of selection bias because the entire article is a randomized control trial using probability sampling techniques, clear research protocols such as the CONSORT diagram with the presentation of statistical data, both significant and insignificant. In addition, selection bias is also low because the entire study uses instruments that have been tested for reliability and validity.

1. Is it clear in the study what is the "cause" and what is the "effect?" (i.e., there is no confusion about which variable comes first)?

2. Were the participants included in any comparisons similar?

3. Were the participants included in any comparisons receiving similar treatment/care, other than the exposure or intervention of interest?

4. Was there a control group?

5. Were there multiple measurements of the outcome both pre and post the intervention/ exposure?

6. Was follow-up complete and if not, were differences between groups in terms of their follow up adequately described and analyzed?

7. Were the outcomes of participants included in any comparisons measured in the same way?

8. Were outcomes measured in a reliable way?

9. Was appropriate statistical analysis used?

Table 2 shows the score of the included research articles is 9 , which indicates that the quality of the research article reporting is very good. However, the included study had a moderate risk of selection bias because it did not use a randomized procedure for sampling in both the intervention and control groups. However, regarding the reporting of the overall results, the study shows statistically significant or insignificant data. All studies suggest that further research is carried out, hoping that the number of samples will be enlarged by random selection procedures or probability sampling techniques.

\section{Study characteristics}

The characteristics of the studies included in this systematic review were scattered across countries with different types of telenursing. The distribution of study sites from articles included in the systematic review is shown in Table 3.
Table 3: Distribution of study sites from articles included in the systematic review

\begin{tabular}{ll}
\hline Place of study & Number of articles \\
\hline Asia & 2 \\
$\quad$ China & 1 \\
$\quad$ Malaysia & \\
America & 1 \\
$\quad$ Michigan-USA & \\
Australia & 1 \\
$\quad$ Brisbane, Australia & 2 \\
Sydney, Australia & 7 \\
Total & 7 \\
\hline
\end{tabular}

Table 3 shows that the included studies were conducted in Asia [18], [26], [27], Holmes-Rovner et al. in America [20], and in Australia [23], [24], [25]. All articles included in the systematic review used English, while none of the articles in Indonesian were included because they did not meet the eligibility criteria in the selection process. The study timeframe included was 2008-2019. A total of 3313 participants were included (average age 58.88); the largest number of samples was 822 participants [26] and the least in the study as many as 95 participants [18]. The study characteristics are summarized in Table 4, which consists of authors, country, intervention group, control group, population, and sample, mean age (SD), time of measurement, and intervention effects.

\section{Description of the health education intervention by telenursing}

\section{Text messages}

Five studies $(n=2358)$ used text message media, including WhatsApp text message, to provide health education about the components of self-care for CAD patients, including; general information regarding CAD, risk factors for PAC, a healthy lifestyle (smoking, diet, and physical activity), secondary prevention of chest pain, and medication adherence reminders [18], [23], [24], [27], one study discussed risk factor monitoring [27] and one study on secondary preventive management of chest pain, as well as two studies of medication adherence. Overall, studies reported health education by telenursing using text message media as a simple intervention and feasible to improve the management of CAD and reduce risk factors.

\section{Effects of text message media on self-care abilities}

Studies that discuss text message media as a whole assess the components of self-care in the form of patient compliance in maintaining a healthy lifestyle that has a good effect based on the results of statistical tests in each study, including; maintaining blood pressure [23], [26]; body mass index [24], [26], [27]; hemoglobin A1c (HbA1c) levels [23], [27]; fasting blood glucose [27]; systolic and diastolic blood pressure [23], [26], [27]; low-density lipoprotein cholesterol (LDL-c) [24], [27]; physical 
Table 4: Study summary included in the systematic review

\begin{tabular}{|c|c|c|c|c|c|c|c|}
\hline $\begin{array}{l}\text { Author (year) } \\
\text { and country }\end{array}$ & Intervention group & Control group & $\begin{array}{l}\text { Population and } \\
\text { sample }\end{array}$ & Mean age (SD) & $\begin{array}{l}\text { Outcome measure of } \\
\text { self-care ability }\end{array}$ & $\begin{array}{l}\text { Measurement } \\
\text { time point }\end{array}$ & Effect of the intervention \\
\hline $\begin{array}{l}\text { Tang et al. [18], } \\
\text { Malaysia }\end{array}$ & $\begin{array}{l}\text { Text messages } \\
\text { through the } \\
\text { WhatsApp } \\
\text { application about } \\
\text { CAD risk factor } \\
\text { education and a } \\
\text { healthy lifestyle }\end{array}$ & $\begin{array}{l}\text { Without WhatsApp } \\
\text { text messages } \\
\text { and only receiving } \\
\text { standard care by } \\
\text { the hospital }\end{array}$ & $\begin{array}{l}\text { 95 CAD patients, } \\
\text { intervention group } \\
n=47 \text { control group } \\
n=47\end{array}$ & $59.9 \pm 12.39$ & $\begin{array}{l}\text { Knowledge and a } \\
\text { healthy lifestyle }\end{array}$ & $\begin{array}{l}\text { Baseline and } \\
\text { after } 3 \text { months }\end{array}$ & $\begin{array}{l}\text { The results of the split plot ANOVA analysis } \\
\text { showed that the mobile application had a } \\
\text { significant and positive effect on patient } \\
\text { knowledge }(p<0.001) \text {. Mobile messaging } \\
\text { also significantly improved the healthy } \\
\text { lifestyle setting of } C A D \text { patients } P<0.001\end{array}$ \\
\hline $\begin{array}{l}\text { Huo et al. [27], } \\
\text { China }\end{array}$ & $\begin{array}{l}\text { Secondary } \\
\text { prevention text } \\
\text { messages } 6 \text { times } \\
\text { a week for } 6 \\
\text { months }\end{array}$ & $\begin{array}{l}\text { Text message } \\
\text { thanks at } 2 \text { times/ } \\
\text { month for } 6 \text { months }\end{array}$ & $\begin{array}{l}502 \text { patients } \\
\text { with CAD and } \\
\text { DM (intervention } \\
\mathrm{n}=251 \text { and control } \\
\mathrm{n}=251 \text { ) }\end{array}$ & $59.5 \pm 9.3$ & $\begin{array}{l}\text { HbA1C levels, fasting } \\
\text { blood glucose, systolic } \\
\text { blood pressure, LDL } \\
\text { cholesterol (low-density } \\
\text { lipoprotein), body mass } \\
\text { index, and physical } \\
\text { activity from baseline to } \\
6 \text { months }\end{array}$ & $\begin{array}{l}\text { Baseline and } \\
\text { after } 6 \text { months }\end{array}$ & $\begin{array}{l}\text { There was a more significant decrease in } \\
\text { the HbA1C value of the intervention group } \\
\text { before and after } 6 \text { months of treatment when } \\
\text { compared to the control group. Secondary } \\
\text { results were a change in the proportion of } \\
\text { patients who achieved HbA1C<7\%, fasting } \\
\text { blood glucose, systolic blood pressure, } \\
\text { LDL cholesterol (low-density lipoprotein), } \\
\text { body mass index, and physical activity } \\
\text { from baseline to } 6 \text { months. Text message } \\
\text { intervention resulted in better glycemic } \\
\text { control in patients with diabetes mellitus and } \\
\text { CAD. Although this benefits mechanism } \\
\text { remains to be investigated, the results } \\
\text { suggest that a simple and culturally sensitive } \\
\text { mobile text messaging program can provide } \\
\text { valuable and feasible benefits to improve } \\
\text { disease self-management }\end{array}$ \\
\hline $\begin{array}{l}\text { Haider } \\
\text { et al. [23], } \\
\text { Sydney }\end{array}$ & $\begin{array}{l}\text { Text messages } \\
\text { contain } \\
\text { smoking, diet, } \\
\text { physical activity, } \\
\text { and general } \\
\text { information about } \\
\text { cardiovascular } \\
\text { disease, including } \\
\text { secondary } \\
\text { prevention such } \\
\text { as chest pain } \\
\text { and medication } \\
\text { adherence }\end{array}$ & $\begin{array}{l}\text { Without text } \\
\text { messages }\end{array}$ & $\begin{array}{l}229 \mathrm{DM} \text { and } \mathrm{CAD} \\
\text { patients (intervention } \\
\mathrm{n}=111 \text { and control } \\
\mathrm{n}=118 \text { ) }\end{array}$ & $59.3 \pm 9.0$ & $\begin{array}{l}\text { Cholesterol, blood } \\
\text { pressure, body mass } \\
\text { index, HbA1C, waist/ } \\
\text { hip circumference, and } \\
\text { smoking status }\end{array}$ & $\begin{array}{l}\text { Baseline } \\
\text { and after } \\
\text { the 6-month } \\
\text { intervention }\end{array}$ & $\begin{array}{l}\text { The main results of the study using the } \\
\text { analysis of covariance (ANCOVA) test } \\
\text { after } 6 \text { months of treatment showed that } \\
\text { the mean difference in SBP was } 7.6 \\
\mathrm{mmHg}(95 \% \mathrm{Cl} 11.8,3.37, P=0.0003) \text { and } \\
\text { a DBP of } 3.7 \mathrm{mmHg}(95 \% \mathrm{Cl} 6.12,1.24 \text {, } \\
P=0.003) \text {. The mean difference in LDLc in } \\
\text { the intervention group, compared to the } \\
\text { control group, was } 0.05 \mathrm{mmol} / \mathrm{L}(95 \% \mathrm{Cl} \\
0.27,0.18, P=0.813) \text { and in triglycerides } \\
0.29 \mathrm{mmol} / \mathrm{L}(95 \% \mathrm{Cl} 0.59 .01, P=0.035) \text {. } \\
\text { The difference in mean body mass index } \\
\text { was } 0.89 \mathrm{~kg} / \mathrm{m}^{2}(95 \% \mathrm{Cl} 2.74,0.95 \text {, } \\
P<0.0001) \text { in the intervention group, waist } \\
\text { circumference } 3.98 \mathrm{~cm} \text { (95\% Cl } 8.57 \text {, } \\
0.61, P<0.0001) \text { and hip circumference } \\
3.26 \mathrm{~cm}(95 \% \mathrm{Cl}-7.67,1.16, P=0.0006) \text {, } \\
\text { compared to the control group. The mean } \\
\text { difference in } \mathrm{HbA} 1 \mathrm{c} \text { between the control } \\
\text { and intervention groups was } 0.39 \%(95 \% \\
\mathrm{Cl} 0.88,0.11, P=0.126) \text {. More participants } \\
\text { in the intervention at } 6 \text { months quit } \\
\text { smoking than the control group (RR } 1.27 \text {, } \\
95 \% \mathrm{Cl} 1.06,1.51, P=0.0041) \text {. In } \mathrm{CAD} \\
\text { patients with type } 2 \mathrm{DM} \text {, lifestyle-focused } \\
\text { text message interventions resulted in a } \\
\text { significant reduction in risk factors }\end{array}$ \\
\hline $\begin{array}{l}\text { Santo et al. [24], } \\
\text { Sydney }\end{array}$ & $\begin{array}{l}\text { Text messages } \\
4 \text { times a week for } \\
6 \text { months, where } \\
\text { one text message } \\
\text { per week contains } \\
\text { a reminder of } \\
\text { the patient's } \\
\text { diet. Besides, } \\
\text { the intervention } \\
\text { group received } \\
\text { semi-personal } \\
\text { text messages } \\
\text { containing } \\
\text { suggestions, } \\
\text { motivation, } \\
\text { and support for } \\
\text { changing lifestyle } \\
\text { behaviors. } \\
\text { Text message } \\
\text { content is based } \\
\text { on secondary } \\
\text { prevention } \\
\text { guidelines by the } \\
\text { Australian Heart } \\
\text { Foundation }\end{array}$ & $\begin{array}{l}\text { Without text } \\
\text { messages (standard } \\
\text { care) }\end{array}$ & $\begin{array}{l}710 \text { coronary heart } \\
\text { patients, intervention } \\
n=338 \text { control } n=351\end{array}$ & $57.6 \pm 9.18$ & Diet compliance & $\begin{array}{l}\text { Baseline and } \\
\text { after } 6 \text { months } \\
\text { of intervention }\end{array}$ & $\begin{array}{l}\text { The results were analyzed using } \\
\text { log-binomial regression for categorical } \\
\text { variables and covariance analysis } \\
\text { for numerical variables. Of a total of } \\
710 \text { patients, } 54 \% \text { followed } \geq 4 \text { dietary } \\
\text { guideline recommendations ( } 53 \% \\
\text { intervention vs. } 56 \% \text { control, } P=0.376 \text { ) at } \\
\text { baseline. After } 6 \text { months, the intervention } \\
\text { group had a significantly higher } \\
\text { proportion of patients adhering to } \geq 4 \\
\text { recommendations ( } 314,93 \% \text { ) compared } \\
\text { to the control group }(264,75 \%, \text { RR } 1.23 \text {, } \\
95 \% \mathrm{Cl} 1.15-1.31, P<0.001) \text {. Besides, } \\
\text { patients in the intervention group reported } \\
\text { consuming more vegetables, fruit, and fish } \\
\text { per week; less takeaway food consumption } \\
\text { per week; and better control of salt intake. } \\
\text { Furthermore, there was a significant } \\
\text { mediational effect of increased adherence } \\
\text { to the recommended association between } \\
\text { the intervention and LDL cholesterol } \\
\text { levels ( } p<0.001 \text { ) and body mass index at } 6 \\
\text { months follow-up ( } p=0.005) \text {. Text message } \\
\text { interventions that focus on lifestyle } \\
\text { changes effectively increase adherence } \\
\text { to recommended dietary guidelines, } \\
\text { specifically increasing the consumption } \\
\text { of vegetables, fruit, fish, food, and salt } \\
\text { intake reported directly by participants. } \\
\text { This simple and measurable text message } \\
\text { intervention could be used to improve diet } \\
\text { in coronary heart patients }\end{array}$ \\
\hline
\end{tabular}


Table 4: (Continued)

\begin{tabular}{|c|c|c|c|c|c|c|c|}
\hline $\begin{array}{l}\text { Author (year) } \\
\text { and country }\end{array}$ & Intervention group & Control group & $\begin{array}{l}\text { Population and } \\
\text { sample }\end{array}$ & Mean age (SD) & $\begin{array}{l}\text { Outcome measure of } \\
\text { self-care ability }\end{array}$ & $\begin{array}{l}\text { Measurement } \\
\text { time point }\end{array}$ & Effect of the intervention \\
\hline $\begin{array}{l}\text { Zheng et al. [26], } \\
\text { China }\end{array}$ & $\begin{array}{l}\text { Receive six text } \\
\text { messages per } \\
\text { week for } 6 \text { months } \\
\text { sent directly by the } \\
\text { computer system. } \\
\text { Text messages } \\
\text { contain educational } \\
\text { and motivational } \\
\text { information related } \\
\text { to CAD-specific } \\
\text { information, control } \\
\text { of risk factors, } \\
\text { physical activity, } \\
\text { and medication } \\
\text { adherence }\end{array}$ & $\begin{array}{l}\text { Usual care and } \\
\text { two thank you text } \\
\text { messages per } \\
\text { month }\end{array}$ & $\begin{array}{l}822 \text { CAD patients, } \\
\text { intervention } n=411 \\
\text { controls } n=411\end{array}$ & $56.4 \pm 9.5$ & $\begin{array}{l}\text { Secondary prevention } \\
\text { increases risk factor } \\
\text { control in patients with } \\
\text { CAD }\end{array}$ & $\begin{array}{l}\text { Baseline and } \\
\text { after } 6 \text { months } \\
\text { of intervention }\end{array}$ & $\begin{array}{l}\text { The main results of the study used } \\
\text { covariance analysis. It was found that } \\
\text { after } 6 \text { months of intervention, systolic } \\
\text { blood pressure was not significantly } \\
\text { lower in the intervention group compared } \\
\text { to the control group (SD) of } 3.2(14.3) \\
\text { mmHg and } 2.0 \text { (15.0) mmHg (p>0.05). } \\
\text { There were no significant differences } \\
\text { between the two groups in LDL-C levels, } \\
\text { physical activity, body mass index, and } \\
\text { smoking status. Nearly, all the patients } \\
\text { in the intervention group reported text } \\
\text { messages that were useful ( } 96.1 \%) \text {, } \\
\text { easy to understand ( } 98.8 \% \text { ), appropriate } \\
\text { frequency (93.8\%), and reported } \\
\text { being willing to accept future text } \\
\text { messages ( } 94.8 \% \text { ). Text messages } \\
\text { supporting the secondary prevention } \\
\text { of CAD patients did not lead to a more } \\
\text { significant reduction in blood pressure at } 6 \\
\text { months. Still, cell phone text messages for } \\
\text { secondary prevention were feasible and } \\
\text { acceptable to patients }\end{array}$ \\
\hline $\begin{array}{l}\text { Hawkes } \\
\text { et al. [25], } \\
\text { Brisbane }\end{array}$ & $\begin{array}{l}\text { Education was } \\
\text { given through } \\
10 \text { phone calls } \\
\text { with } 30 \text { min for } 6 \\
\text { months regarding } \\
\text { CAD risk factor } \\
\text { management }\end{array}$ & $\begin{array}{l}\text { Without phone } \\
\text { calls (standard care) }\end{array}$ & $\begin{array}{l}430 \text { patients with } \\
\text { myocardial infarction }\end{array}$ & $60.6 \pm 11.8$ & $\begin{array}{l}\text { Quality of life and } \\
\text { healthy behavior }\end{array}$ & $\begin{array}{l}\text { Baseline and } \\
\text { after } 6 \text { months } \\
\text { of intervention }\end{array}$ & $\begin{array}{l}\text { The results of statistical analysis showed } \\
\text { that the intervention group achieved a } \\
\text { significantly higher quality of life score } \\
\text { than the control group, with a } P \text { value } \\
\text { for mental components ( } p=0.02 \text { ), } \\
\text { social function ( } p=0.04 \text { ), and emotional } \\
\text { roles ( } p=0.03 \text { ). In addition, the } \\
\text { intervention group also better met } \\
\text { the recommended level of physical } \\
\text { activity }(p=0.02) \text { body mass index ( } p=0.05 \text { ), } \\
\text { vegetable intake ( } p=0.04) \text {, and alcohol } \\
\text { consumption ( } p=0.05 \text { ). Secondary } \\
\text { prevention programs implemented over } \\
\text { the telephone can significantly improve } \\
\text { health outcomes and fill treatment gaps for } \\
\text { myocardial infarction }\end{array}$ \\
\hline $\begin{array}{l}\text { Holmes-Rovner } \\
\text { et al. [20], } \\
\text { Michigan }\end{array}$ & $\begin{array}{l}\text { The } \\
\text { telephone-based } \\
\text { counseling } \\
\text { intervention } \\
\text { consisted of } \\
\text { six sessions } \\
\text { over } 8 \text { months } \\
\text { on guidelines } \\
\text { for improving } \\
\text { adherence to }\end{array}$ & Standard care & $\begin{array}{l}525 \text { acute coronary } \\
\text { syndrome (ACS) } \\
\text { patients }(n=268 \\
\text { intervention group } \\
\text { and } n=257 \text { control } \\
\text { group }\end{array}$ & - & $\begin{array}{l}\text { Secondary prevention; } \\
\text { behavior and treatment }\end{array}$ & $\begin{array}{l}\text { Baseline and } \\
\text { after } 8 \text { months }\end{array}$ & $\begin{array}{l}\text { There were no statistically significant } \\
\text { differences in the treatment used } \\
\text { between the intervention and control } \\
\text { groups; beta-blockers, aspirin, } \\
\text { angiotensin (enzyme inhibitor), angiotensin } \\
\text { receptor blockers, and lipid-lowering drugs } \\
\text { before the intervention, } 3 \text { months, and } 8 \\
\text { months. Whereas in the intervention group, } \\
\text { there was an increase in physical activity } \\
\text { at } 3 \text { and } 8 \text { months (OR=1.53, } P<0.02 \text { ). } \\
\text { There were no significant differences in } \\
\text { participants' smoking cessation efforts and } \\
\text { weight loss and no differences in functional } \\
\text { status or quality of life with intention to } \\
\text { treat. } \\
\text { Post-hospitalized telephone counseling } \\
\text { for ACS patients effectively improves } \\
\text { short-term secondary prevention but does } \\
\text { not affect long-term lifestyle changes }\end{array}$ \\
\hline
\end{tabular}

activity, dietary adherence (consumption of fruits, vegetables, and fish) [18], [24]; and control of salt intake and smoking cessation [24], [26].

\section{Phone call}

Two studies $(n=955)$ used telephone calls to provide health education with a duration of $30 \mathrm{~min}$ of administration 10 times for 6 months [25] and six sessions for 8 months [20]. The education provided is a component of self-care, including; healthy behavior to control risk factors and secondary prevention (medication, smoking cessation, and risk factor management). The study as a whole explains that secondary prevention by providing education through phone calls can improve health outcomes in the form of short-term behavior changes, filling treatment gaps but not affecting long-term lifestyle changes.

\section{Effects of telephone call media on self-care abilities}

The telephone call media used to provide health education by telenursing were carried out in two studies assessing the self-care component as the main outcome including; physical activity recommended better in the intervention group $(p=0.02$; odds ratio $[O R]=1.53)$, body mass index $(p=0.05)$, vegetable intake $(p=0.04)$, and alcohol consumption $(p=0.05)$ [20], [25]. However, there was no significant difference between intervention and control in the self-care component of treatment adherence, and it had no statistical effect on the intervention group [20]. 


\section{Discussion}

This systematic review identified, assessed, and synthesized seven published articles evaluating health education by telenursing as a secondary prevention program for the self-care ability of patients with CAD. The quality of the reviews was good (mean study scores of RCT 11 and quasi-experiment nine were assessed independently by three reviewers [VL, YT, and $\mathrm{N}]$ using the JBI critical appraisal, using the JBI critical appraisal tool).

There is heterogeneity in the components of self-care assessed, educational materials, and the intensity of provision, measurement results, and implementation media. The power of systematic review includes a systematic approach to the data collection process. The data extraction model used allows the reviewer to capture all relevant information regarding the included study.

The implementation of healthy self-care behavior reduces the risk of disease incidence, and the mechanism underlying the effect can be said to be protective against heart health, mainly related to self-care maintenance components such as smoking cessation, maintaining a normal BMI, routine physical activity, reducing dietary sodium intake, reducing alcohol use. And keep a healthy diet, low cholesterol, standard $\mathrm{BP}$ control, and average fasting plasma glucose.

The health education provided focuses on providing general information regarding $C A D$, risk factors for CAD, a healthy lifestyle (smoking, diet, and physical activity), secondary prevention of chest pain, and medication adherence reminders. The results in this review are in line with those of Riegel et al. In the case of CAD, the focus of intervention on lifestyle modification will produce better clinical outcomes.

The most often used medium for implementing education is text messages using the WhatsApp application or text messages available on cell phones. Five studies explain this, while two studies are related to the media of telephone calls.

All included studies did not use a combination of text messages and telephone calls but were carried out separately. In fact, according to Boroumand and Moeini [29], in their research, giving short messages (SMS) and phone calls effectively increase the selfefficacy of patients with CAD. Likewise, a previous systematic review [30] states that web-based technology is most often used and helps provide health education so that the utilization of technological developments is better to use.

The results of this review reveal that the use of text message media is more frequently used when compared to telephone calls. That is in line with the evaluation results presented by Zheng et al. [26] that the provision of health education with text message media is applicable (96.1\%), easy to understand (98.8\%), according to frequency (93.8\%). And willing to receive future text messages (94.8\%). The results obtained on changes in the self-care component based on a review of the five included studies also stated that it had a statistical effect, including maintaining blood pressure, body mass index, HbA1c levels, fasting blood glucose, systolic and diastolic blood pressure, LDL cholesterol, physical activity, and maintaining compliance.

The media calls discussed in the included study affected only changes in physical activity, body mass index, vegetable, and alcohol consumption but did not affect treatment adherence. If analyzed based on the studies' findings, the duration and time of administration were too long with a low frequency of education (10 times for 6 months and 6 times for 8 months).

In line with the theory of cognitive decline, which is a factor that influences self-care behavior by Riegel et al. [31], it is stated that CAD patients have cognitive abilities that are decreasing day by day concerning age and the effect of heart disease experienced. Participants included in the systematic review had an average age of 58.88, which indicates that age affects their cognitive abilities in understanding the educational material provided. In comparison, the use of technological devices in implementing telenursing, such as telephone calls, can increase good results for patients with different diagnoses, however. The implementation of education through telephone calls is essential using the proper protocol; it is significant because it has clear objectives using communication principles in interacting with patients and carrying out assessment and education [32].

The use of technology in providing education by nurses provides younger access for patients.

However, providing education is also essential to consider that the patient's health literacy ability will affect the increase in knowledge and decision-making to achieve better self-care abilities. Overall, the included studies were studies conducted in other countries and were proven to influence the self-care component based on the results of statistical tests performed by each study with $p$-value $(<0.05)$. However, if applied in Indonesia, it is important to consider people's literacy skills because studies conducted in 34 provinces in Indonesia are still low [32]. Literacy in the use of health education media by telenursing will be beneficial in encouraging patients to change their self-care behavior so that it can become an essential component that is considered in providing health education such as text messages and telephone calls.

\section{Limitations of systematic review studies}

Limitations in the systematic review during the literature identification process, analysis to the 
compilation, and summary process are as follows: (1)This systematic review is limited empirically because it only identifies studies in Indonesian and English, although studies in Indonesian are not included. After all, the research is related to the disease population, coronary arteries have not been done or have been missed in the thesis, thesis, and seminar proceedings that are not published in the online database. (2) The included studies only cover countries in Asia, America, and Australia, thereby reducing the generalizability of the results to the CAD patient population. (3) The expected results of assessing self-care are generally not found in the included studies so that the reviewers identify the results based on the components of self-care. This makes it difficult for reviewers to perform statistical data analysis (meta-analysis) so that reviewers only carry out the narrative analysis.

\section{Conclusion and Recommendation}

This study showed that health education with telenursing is very effective in improving the self-care abilities of CAD patients. Health education media through telenursing that can be done to CHD patients to improve self-care abilities include text messages and phone calls. Furthermore, the most effective media to provide education based on reviewer analysis is text message media. This systematic review has decent implications for nursing science, so nurses can provide ongoing education and directly find out the progress of CAD patients without being hindered by distance and time. Thus, nurses can determine the clinical condition of CAD patients to prevent recurrence or repeated attacks. For further researchers, it is crucial to develop a protocol for implementing the provision of education properly, compiling specific materials about the needs of patients in the process of recovering their physical condition. In addition to educational materials, the availability of patients in receiving education must be considered so that the implementation time runs effectively.

\section{References}

1. Nag T, Ghosh A. Cardiovascular disease risk factors in Asian Indian population : A systematic review. J Cardiovasc Dis Res. 2014;4(4):222-8. https://doi.org/10.1016/j.jcdr.2014.01.004 PMid:24653585

2. Khan M, Lamelas P, Musa H, Paty J, Mccready T, Nieuwlaat R, et al. Development, testing, and implementation of a training curriculum for nonphysician health workers to reduce cardiovascular disease. Glob Heart. 2018;13(2):93-100.e1. https://doi.org/10.1016/j.gheart.2017.11.002

\section{PMid:29331282}

3. WHO. WHO, Cardiovascular Diseases (CVDs) Keyfacts. Geneva: WHO; 2017.

4. Ministry of Health Indonesia. Ministry of Health RI. Indonesia: Ministry of Health Indonesia; 2018. p. 1. Available from: https:// www.kemkes.go.id/article/view/18111200002/rs-jantungharapan-kita-pengampu-rujukan-kardiovaskular.html

5. Indonesian Center for Health Data and Information. Heart Health Situation. Indonesia: Indonesian Center for Health Data and Information RI; 2014. p. 3. Available from: https://www.who. int/reproductivehealth/self-care-interventions/definitions/en. https://doi.org/10.1017/CBO9781107415324.004

6. WHO. Pocket Guidelines for Assessment and Management of Cardiovascular Risk: (WHO/ISH Cardiovascular Risk Prediction Charts for the African Region). Geneva: World Health Organization; 2007. p. 1-30.

7. Knuuti J, Wijns W, Saraste A, Capodanno D, Barbato E, FunckBrentano C, et al. 2019 ESC Guidelines for the diagnosis and management of chronic coronary syndromes. Eur Heart J. 2020;41(3):407-7. https://doi.org/10.1093/eurheartj/ehz425 PMid:31504439

8. Woods S, Froelicher ES, Motzer SU, Bridges E. Cardiac Nursing. $6^{\text {th }}$ ed. China: Wolters Kluwer Health; 2010. p. 511-36.

9. WHO. (2013). Implementation tools Package of Essential Noncommunicable (PEN) disease interventions for primary health care in low-resource settings. Mscforum. Org, 210.

10. Saffouh M, Hajj E, Jaam MJ, Awaisu A. Effect of pharmacist care on medication adherence and cardiovascular outcomes among patients post-acute coronary syndrome: A systematic review. Res Social Adm Pharm. 2017;14:507-20. https://doi.org/10.1016/j. sapharm.2017.06.004

PMid:28641999

11. Peterson JC, Link AR, Jobe JB, Winston GJ, Klimasiewfski EM, Allegrante JP. Developing self-management education in coronary artery disease. Hear Lung. 2014;43(2):133-9. https:// doi.org/10.1016/j.hrtIng.2013.11.006

PMid:24373484

12. Avezum Á, Perel P, Oliveira GB, Lopez-Jaramillo P, Restrepo G, Loustalot $F$, et al. Challenges and opportunities to scale up cardiovascular disease secondary prevention in latin america and the caribbean. Glob Heart. 2018;13(2):83-91. https://doi. org/10.1016/j.gheart.2017.05.002

PMid:29032937

13. Bitton A, Choudhry NK, Matlin OS, Swanton K, Shrank WH. The impact of medication adherence on coronary artery disease costs and outcomes: A systematic review. Am J Med. 2013;126(4):357.e7-27. https://doi.org/10.1016/j. amjmed.2012.09.004

PMid:23507208

14. WHO. Technical Package for Cardiovascular Disease Management in Primary Health Care, Report. Geneva: WHO; 2016.

15. Ahn S, Song R, Choi SW. Effects of self-care health behaviors on quality of life mediated by cardiovascular risk factors among individuals with coronary artery disease: A structural equation modeling approach. Asian Nurs Res (Korean Soc Nurs Sci). 2016;10(2):158-63. https://doi.org/10.1016/j. anr.2016.03.004

PMid:27349674

16. Kang Y, Yang IS. Cardiac self-efficacy and its predictors in patients with coronary artery diseases. J Clin Nurs. 2013;22(17-18):2465-73. https://doi.org/10.1111/jocn.12142 PMid:23441807

17. Bikmoradi A, Masmouei B, Ghomeisi M, Roshanaei G. Impact of Tele-nursing on adherence to treatment plan in discharged 
patients after coronary artery bypass graft surgery: A quasiexperimental study in Iran. Int J Med Inform. 2015;86:43-8. https://doi.org/10.1016/j.ijmedinf.2015.12.001

PMid:26725694

18. Tang YH, Chong MC, Chua YP, Chui PL, Tang LY, Rahmat N. The effect of mobile messaging apps on cardiac patient knowledge of coronary artery disease risk factors and adherence to a healthy lifestyle. J Clin Nurs. 2018;27(23-24):4311-20. https:// doi.org/10.1111/jocn.14538

PMid:29777560

19. Janssen-Boyne JJ, Vrijhoef HJ, Spreeuwenberg M, de Weerd G, Kragten J, Gorgels AP. Effects of tailored telemonitoring on heart failure patients' knowledge, self-care, self-efficacy and adherence: A randomized controlled trial. Eur J Cardiovasc Nurs. 2014;13(3):243-52. https://doi.org/10.1177/1474515113487464 PMid:23630403

20. Holmes-Rovner $M$, Stommel $M$, Corser WD, Olomu $A$, Holtrop JS, Siddiqi A, et al. Does outpatient telephone coaching add to hospital quality improvement following hospitalization for acute coronary syndrome? J Gen Intern Med. 2008;23(9):146470. https://doi.org/10.1007/s11606-008-0710-1 PMid:18618189

21. Ong MK, Romano PS, Edgington $\mathrm{S}$, Aronow HU, Auerbach $A D$, Black JT, et al. Effectiveness of remote patient monitoring after discharge of hospitalized patients with heart failure the better effectiveness after transition-heart failure (BEAT-HF) randomized clinical trial. JAMA Intern Med. 2016;176(3):310-8. https://doi.org/10.1001/jamainternmed.2015.7712 PMid:26857383

22. Polit DF, Beck CT. Nursing research: Generating and Assessing Evidence for Nursing Practice. $9^{\text {th }}$ ed. China: Wolters Kluwer Health; 2012. p. 218-21.

23. Haider R, Hyun K, Cheung NW, Redfern J, Thiagalingam A, Chow CK. Effect of lifestyle focused text messaging on risk factor modification in patients with diabetes and coronary heart disease: A sub-analysis of the TEXT ME study. Diabetes Res Clin Pract. 2019;153:184-90. https://doi.org/10.1016/j. diabres.2019.04.030

PMid:31063856

24. Santo K, Hyun K, de Keizer L, Thiagalingam A, Hillis GS Chalmers $\mathrm{J}$, et al. The effects of a lifestyle-focused textmessaging intervention on adherence to dietary guideline recommendations in patients with coronary heart disease: An analysis of the TEXT ME study. Int J Behav Nutr Phys Act. 2018;15(1):45. https://doi.org/10.1186/s12966-018-0677-1 PMid:29792202

25. Hawkes AL, Patrao TA, Atherton J, Ware RS, Taylor CB, O'Neil A, et al. Effect of a telephone-delivered coronary heart disease secondary prevention program (proactive heart) on quality of life and health behaviours: Primary outcomes of a randomised controlled trial. Int J Behav Med. 2013;20(3):413-24. https://doi. org/10.1007/s12529-012-9250-5

\section{PMid:23012159}

26. Zheng X, Spatz ES, Bai X, Huo X, Ding Q, Horak P, et al. Effect of text messaging on risk factor management in patients with coronary heart disease: The CHAT randomized clinical trial. Circ Cardiovasc Qual Outcomes. 2019;12(4):e005616. https://doi. org/10.1161/CIRCOUTCOMES.119.005616 PMid:30998400

27. Huo X, Krumholz HM, Bai X, Spatz ES, Ding Q, Horak P, et al Effects of mobile text messaging on glycemic control in patients with coronary heart disease and diabetes mellitus. J Cardiovasc Qual Outcomes. 2019;12(9):e005805. https://doi.org/10.1161/ CIRCOUTCOMES.119.005805

PMid:31474119

28. Varaei S, Shamsizadeh M, Cheraghi MA, Talebi M, Dehghani A, Abbasi A. Effects of a peer education on cardiac self-efficacy and readmissions in patients undergoing coronary artery bypass graft surgery: A randomizedcontrolled trial. Nurs Crit Care. 2017;22(1):19-28. https://doi. org/10.1111/nicc.12118

PMid:25349051

29. Boroumand S, Moeini M. The effect of a text message and telephone follow-up program on cardiac self-efficacy of patients with coronary artery disease: A randomized controlled trial. Iran J Nurs Midwifery Res. 2016;21(2):171-6. https://doi. org/10.4103/1735-9066.178243 PMid:27095991

30. Brørs G, Pettersen TR, Hansen TB, Fridlund B, Hølvold LB, Lund $\mathrm{H}$, et al. Modes of $\mathrm{E}$-health delivery in secondary prevention programmes for patients with coronary artery disease: A systematic review. BMC Health Serv Res. 2019;19(1):364. https://doi.org/10.1186/s12913-019-4106-1 PMid:31182100

31. Riegel B, Moser DK, Buck HG, VaughanDickson V, B.Dunbar S, Lee CS, et al. Self-care for the prevention and management of cardiovascular disease and stroke: A scientific statement for healthcare professionals from the American heart association. J Am Heart Assoc. 2017;6(9):e006997. https://doi.org/10.1161/ JAHA.117.006997

PMid:28860232

32. Wheeler EC, Waterhouse JK. Telephone interventions by nursing students: Improving outcomes for heart failure patients in the community. J Community Health Nurs. 2006;23(3):137-46. https://doi.org/10.1207/s15327655jchn2303_1 PMid:16863399 